\title{
Perceived Benefit of Condom Use Domination on the Perceived Benefit of Sexually Transmitted Infection Screening on Queer in Yogyakarta
}

\author{
Fika Lilik Indrawati'1), Argyo Demartoto²), Ari Natalia Probandari3) \\ ${ }^{1)}$ Masters Program in Public Health, Universitas Sebelas Maret \\ 2)Faculty of Social and Political Sciences, Universitas Sebelas Maret \\ 3)Faculty of Medicine, Universitas Sebelas Maret
}

\begin{abstract}
Background: The negative stigma is inherent in transvestites because it is referred to as one of the sources of the spread of STIs and HIV/ AIDS viruse. In their position as a sex worker who was considered very low and lack of knowledge about reproductive health, the transvestites were infected with STIs and the HIV virus from their sexual partners. This happened because of a lack of information about reproductive health and access to health services for queer. This study aimed to analyze perceived benefit of condom use domination on the perceived benefit of sexually transmitted infection screening on queer.

Subjects and Method: This was a qualitative study with phenomenological approach. Seven representative informants were selected by purposive sampling. The data were collected by indepth interview and focus group discussion. The number of informants at the focus group discussion was eight people.

Results: Most of the informants believed that they were able to avoid or recover from STIs by using safety, namely condoms. They are more convinced that by applying condoms to their partners, it will be more useful as prevention of STIs compared to STI screening, on the grounds that practical condoms are easy to carry and do not hurt when having sexual intercourse.

Conclusion: All transvestites believe that STI screening can be beneficial to their health, but the reality in their behavior is that they believe in condoms as a means of preventing STIs.
\end{abstract}

Keywords: condom, STI screening service, queer

\section{Correspondence:}

Fika Lilik Indrawati. Masters Program in Public Health, Universitas Sebelas Maret. Jl. Ir. Sutami 36 A, Surakarta 57126, Central Java. Email: fika.lilik.indrawati@gmail.com

\section{BACKGROUND}

The existence of STIs has had a major impact in HIV / AIDS control (Ministry of Health, 2011; Provincial AIDS Commission for DIY, 2014). Based on data from the "WHO Online Survey 2012" on online IMS reporter results, Syphilis is a type of STI found in more than 100 countries worldwide, followed by gonorrhea in more than 90 countries, congenital syphilis and chlamydia over 60 countries and herpes more than 40 countries (WHO, 2013). Preventing and treating STIs may reduce the risk of sexually transmitted HIV, especially in populations which are most likely to have multiple sexual partners, such as commercial sex workers and their clients. STI and HIV AIDS prevention and intervention programs undertaken by the Ministry of Health of the Republic of Indonesia and NGOs up to now have been based on riskbased interventions in accordance with the 2011 Integrated Biological and Behavior Survey (STBP) survey results (Ministry of Health, 2011).

The highest prevalence of Syphilis was found in Waria/transvesities (25\%), followed by WPSL (10\%), LSL (9\%), WBP (5\%), 
Risti Potential Men (4\%), WPSTL (3\%), and IDU\%). The highest prevalence of gonorrhea is in WPSL (38\%), followed by transvestites (29\%), LSL (21\%), and WPSTL (19\%). The highest prevalence of chlamydia is in WPSL and WPSTL ( $41 \%$ each), followed by transgender (28\%) and LSL (21\%). The prevalence of gonorrhea and or chlamydia is between $33 \%$ (LSL) and 56\% (WPSL). The search for treatment for health services (STI services) among respondents who had more symptoms of STIs was not done by transvestites compared to other survey populations. From these data, it can be seen that the transvestite population has a high percentage of Syphilis Prevalence and Prevalence of Gonorrhea and or Chlamydia, but most transvestites never make visits to STI Services (Circular Letter No. 129 Year 2013, no date; Province of DIY, 2014).

The number of transvestites in Yogyakarta according to KEBAYA data and records is 412 people. But this figure only shows the transvestites who join the organization KEBAYA and it is not the total number of transvestites throughout the city. 42 of them stated as positive for HIV infection. KEBAYA and the government cooperate in order to decrease the number of STI and HIV/AIDS in transsexuals through sexually transmitted infections (IMS) services provided in several health services such as Gedongtengen, Umbulharjo I Public health centers, RS. Jogja, Edelwise Clinic RS. Sardjito, Puskesmas Kretek and NGO PKBI-DIY (KEBAYA, 2008; PKBI D.

A preliminary study conducted by the researchers by extracting information through interviews with the Chairman and 4 transvestites at NGO KEBAYA shows that the transvestite attentions towards VCT HIV/AIDS is higher than that of STI screening. transvestites have a perception that HIV/AIDS VCT is considered more important than STI screening without them being aware that STI is one factor that increases the likelihood of HIV. If STI events are left alone without proper intervention the target will be difficult to break the chain of HIV/AIDS transmission. Despite knowing places where STI services are, they are sometimes reluctant to seek help either for diagnostic or treatment purposes, due to embarrassment and negative stigma about transvestites. The problem in this study is how the dominance of condom benefit beliefs against the beliefs of the STI screening benefits.

\section{SUBJECTS AND METHOD}

This was a qualitative study with phenomenology approach. Informants in this study were transvestites for about 7 people. Sampling technique in this study was purposive sampling based on criterion based sampling criteria that is transvestite who work as Commercial Sex Worker (PSK) and non-PSK (salon worker, make up artist, entertainment, etc), transvestite with[[[ STI and transsexuals who are not affected by STIs. The next technique was snowball sampling. The researcher asked the NGO chairman to point out the transvestites who were in accordance with the criteria and are willing to be interviewed, until the researcher's needs are met.

The data collection was conducted using in-depth interviews and focus group discussions. In-depth interviews consisted of 7 transvestites and 3 key informants. In the implementation of FGD, informants consisted of 8 transvestites. The data analysis used in this study was interactive model of Miles and Huberman (2007) consisting of 4 steps: data collection, data reduction, presentation and data analysis in the form of conclusion or verification data (Murti, 2013; Moleong, 2010). 


\section{RESULTS}

This study was conducted on November 2014 up to April 2015. The descriptions about perceived benefit of condom use domination on the perceived benefit of sexually transmitted disease screening were as follows: Confidence about the use of STD screening services in this study obtained similar answers. Most informants believe that they can avoid or recover from STD by using safety which was condom. They were more convinced that putting a condom on their partner would be more useful as STD prevention compared to STD screening, for the reason that the condom was practical, easy to carry, and did not hurt during sexual activity.

Some informants said that they were not sure that they were able to avoid STD because they had sexual activity with customers without using safety. Although they already used condoms during sexual activity, however, one of them was still feel unsure that he/she was able to contracted by STD. Because one of the sexual activities was oral sex, at the time of oral sex, the partner of informants did not use condoms because the informant was allergic to condoms. There was a feeling of nausea when the informant performed oral by using a condom.

\section{DISCUSSIONS}

In this study, all the informants believed that STD screening was beneficial for health especially in the prevention of STD. By doing STD screening, it would avoid sexually transmitted diseases and can find out earlier if he/she was exposed to the disease. Another advantage that they get was that they can consult directly with the doctor and got lots of information about STD. However, so far most informants believed that they were able to avoid or recover from STD by using a safety which was condom. They were more convinced that putting a condom on their partner would be more useful as STD prevention compared to STD screening, for the reason that the condom was practical, easy to carry, and did not hurt during sexual activity (Zhao et al., 2012; Solomon et al., 2014).

Some of them stated that they were not sure to avoid or recover from STD due to their activities as sex workers and they have multiple partners. Although they already tried to bring condoms, but there were some partners and customers who were not willing to use the condoms. This was in line with a study done by Yusnita (2012) which stated that sex workers always offer condom use to the customers, but due to low negotiation skills and low bargaining position of sex workers, they did not require condom use to the customers (Corrigan and Watson, 2002; Yusnita, 2012).

Based on the results of the study on transvestites in Kebaya NGO, Yogyakarta, it can be concluded that almost all transvestites believed that STD screening could be beneficial for their health, but the reality in their behavior was more relying on condom as a means of STD prevention.

\section{REFERENCES \\ Corrigan PW, Watson AC (2002). The Para- dox of Self-Stigma and Mental Illness. Clinical Phychology, Science and Practice, 9(1): 35-53.}

KEBAYA. (2008). Profil KEBAYA.

Kementerian Kesehatan RI. (2011). Surveilans Terpadu Biologis dan Perilaku. Jakarta: Forum Nasional Jaringan Kebijakan Kesehatan.

Komisi Penanggulangan AIDS Provinsi DIY. (2014). Layanan Infeksi Menular Seksual (IMS). 
Moleong L (2010). Metode Penelitian Kualitatif Edisi Revisi. Bandung: PT. Remaja Rosda Kaya.

Murti B (2013). Desain dan Ukuran Sampel untuk Penelitian Kuantatif dan Kualitatif di Bidang Kesehatan. Yogyakarta: Gadjah Mada University Press.

PKBI DIY (2007). Waria Kami Memang Ada. DIY: Dinas Kesehatan Provinsi DIY dan Global Fund.

Solomon MM, Mayer KH, Glidden DV, Liu AY, Mcmahan VM, Guanira JV, Chariyalertsak S, et al., (2014). Syphilis Predicts HIV Incidence Among Men and Transgender Women Who Have Sex With Men in a Preexposure Prophylaxis Trial. Clinicaal Infectious Diseases, 59: 1020-1026. doi: $10.1093 / \mathrm{cid} / \mathrm{ciu} 450$.

Surat Edaran No. 129 Tahun 2013.
Pelaksanaan Pengendalian HIV-AIDS dan Infeksi Menular Seksual (IMS). WHO (2013). Baseline Report on Global Sexually Transmitted Infection Surveillance 2012. Switzerland: WHO Press.

Yusnita. (2012). Perilaku Wanita Pekerja Seks Langsung (WPSL) Mewajibkan Penggunaan Kondom untuk Pencegahan HIV_AIDS di Kecamatan Tapung Hulu Kabupaten Kampar Provinsi Riau Tahun 2012. Universitas Indonesia.

Zhao J, Song F, Ren S, Wang Y, Wang L, Liu W, Wan Y, et al. (2012). Predictors of Condom Use Behaviors Based on the Health Belief Model ( HBM ) among Female Sex Workers: A CrossSectional Study in Hubei Province, China. PLoS ONE, 7(11): 1-7. doi: 10.1371/journal.pone.0049542. 